\title{
Advanced Phosphorus Removal and Needs for Recovery by Enhanced Filtration of Municipal Wastewater
}

\author{
Stig Morling1, Mattias Feldthusen² \\ ${ }^{1}$ Sweco Environment AB, Royal Institute of Technology (KTH), Stockholm, Sweden \\ ${ }^{2}$ Director Process \& Product Development, Nordic Water Products AB, Mölndal, Sweden \\ Email: stig.morling@sweco.se, mattias.feldthusen@nordicwater.com
}

How to cite this paper: Morling, S. and Feldthusen, M. (2019) Advanced Phosphorus Removal and Needs for Recovery by Enhanced Filtration of Municipal Wastewater. Journal of Water Resource and Protection, 11, 626-637.

https://doi.org/10.4236/jwarp.2019.115036

Received: April 17, 2019

Accepted: May 26, 2019

Published: May 29, 2019

Copyright () 2019 by author(s) and Scientific Research Publishing Inc. This work is licensed under the Creative Commons Attribution International License (CC BY 4.0).

http://creativecommons.org/licenses/by/4.0/

\begin{abstract}
The need for an advanced and even far reaching phosphorus removal at municipal WWTPs may soon get stipulations in relation to a reuse of phosphorus $(\mathrm{P})$. This paper discusses the possible ways to remove phosphorous from municipal wastewater. This is already an established demand in many countries. However, as $\mathrm{P}$ is a limited raw material, this need for a reuse of $\mathrm{P}$ will become an example of what now is labelled "cyclic economy". For instance, a national demand from the German state is already put in force. In this perspective the advanced filtration techniques will play an interesting role, and most possibly a crucial role. Examples are presented from several municipal WWTPs already in operation with a final polishing treatment step based on chemical precipitation and separation of phosphorus. Typical stable discharge $\mathrm{P}$ levels are found at these plants at levels $<0.05$ to $0.10 \mathrm{ppm}$. The new demands on phosphorus recovery will also call for modified process concepts for the WWTP; for instance, a refined biological phosphorus removal (EBP) attains more attention and he needed very low discharge levels of $\mathrm{P}$, where the enhanced P-removal will include different smart filtration techniques.
\end{abstract}

\section{Keywords}

Phosphorus, Advanced Removal, Chemical Precipitation, Filtration Techniques, Reuse of Purified Water

\section{Background}

For especially industrialized countries the water environment and the concerns of uncontrolled eutrophication have been found as growing concerns for almost a century. This concern now is step-by-step, shared by many countries around 
the world. The problem when it comes to municipal wastewater has been expressed by, inter alia, a relation called the Oxygen Consumption Potential (in the following OCP), see Equation (1). The formula describes the impact on receiving water bodies with respect to the oxygen consumption caused by the discharge of polluted wastewater. The formula was initially outlined by professor Halvard Oedegaard at the Norwegian Technical University in Trondheim (NTH). The relation was presented during the 1980s:

$\mathrm{OCP}=1 \times \mathrm{BOD}+4 \times \mathrm{N}+14 \times \mathrm{N}+100 \times \mathrm{P}$, in $\mathrm{kgO}_{2} / \mathrm{d}$; where;

OCP $=$ Oxygen Consumption Potential, defined as $\mathrm{kg} \mathrm{O}_{2} / \mathrm{d}$;

$1 \times \mathrm{BOD}=$ Organic pollution, defined as $\mathrm{kg} \mathrm{O}_{2} / \mathrm{d}$;

$4 \times \mathrm{N}=$ primary oxygen consumption due to oxidation of ammonia nitrogen into nitrate nitrogen, defined as $\mathrm{kg} \mathrm{O}_{2} / \mathrm{d}$;

$14 \times \mathrm{N}=$ secondary oxygen consumption due to algae growth and decay driven by nitrogen, defined as $\mathrm{kg} \mathrm{O}_{2} / \mathrm{d}$;

$100 \times \mathrm{P}=$ secondary oxygen consumption due to algae growth and decay driven by phosphorus, defined as $\mathrm{kg} \mathrm{O}_{2} / \mathrm{d}$.

According to the relation, the impact of phosphorus on the oxygen balance in a receiving water body is of major importance. This insight had step by step occurred during the $20^{\text {th }}$ century in many industrialized countries. Professor Oedegaard's important contribution to the knowledge was to quantify the impact. However, even earlier in the 1960s in Sweden the concerns for the eutrophication of the surrounding water bodies had started an ambitious program for phosphorus removal, see Morling [1]. The technical development that was initiated by the program is presented in this reference. Within this context the specific development of advanced filtration models is of special interest. The following chapters will explain and point out the potential benefits of an advanced and efficient way to capture phosphorus. As will be presented the advanced filtration of wastewater may also open other options for re-use of treated water.

During some decades the main option for reuse of phosphorus was linked to recycling of the treated and dewatered sludge from municipal wastewater treatment plants. Over many years the focus was the quality defined by the heavy metal content in the sludge. Typical quality requirements were defined with respect to critical heavy metals for $\mathrm{Cd}, \mathrm{Hg}$ and $\mathrm{Pb}$ in relation to the total sludge amounts. To a significant extent these criteria have been satisfied by so-called "upstream" measures. An improvement in this respect has been achieved. Figure 1 illustrates the improvements in Germany during a forty-year period with respect to cadmium and mercury, see [2], Weichmann, B, et al. a similar improvement has been found in Sweden. However, these improvements are now insufficient. The growing understanding of the wastewater complexity has called for more stringent demands. In Germany a radical new pathway has been legislated for the sludge problem, see [2], Weichmann, B, et al. very briefly the following new conditions are outlined:

- A conviction that the resources of phosphorus found in the different mines 


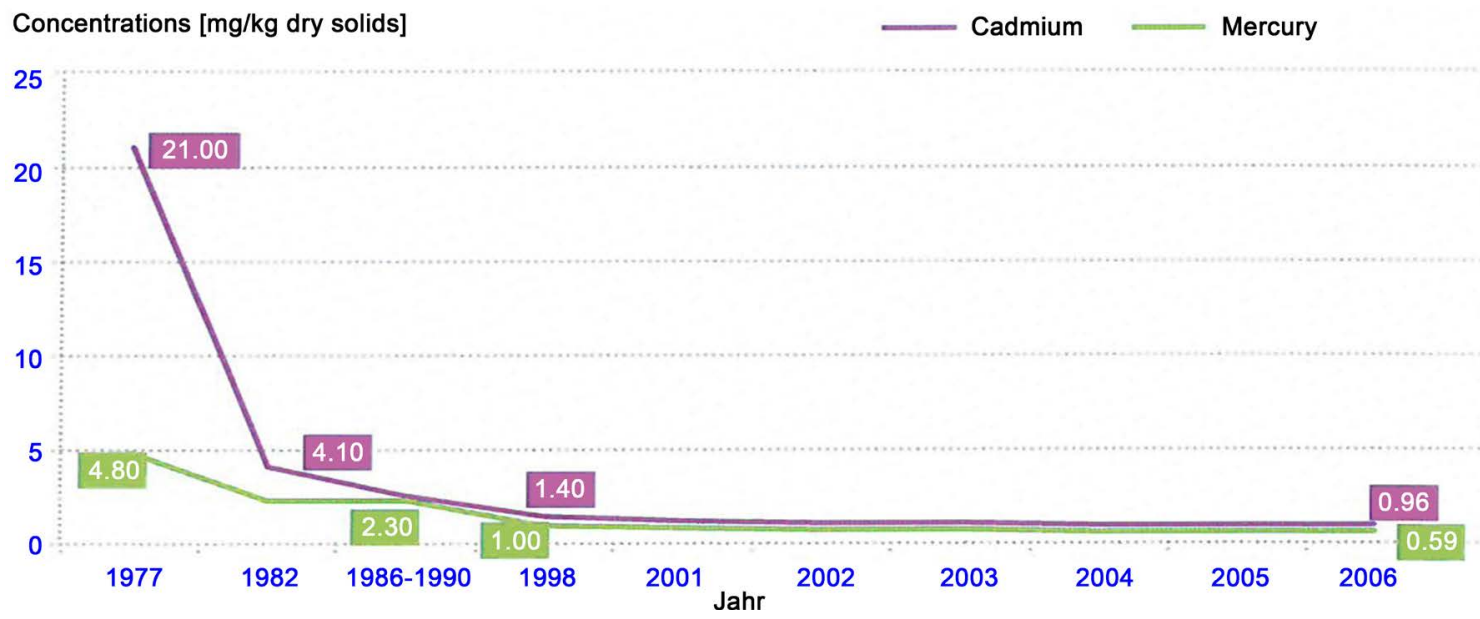

Figure 1. Typical change in heavy metal content in sludge during a 30 year period, here illustrated by the decrease of $\mathrm{Cd}$ and $\mathrm{Hg}$, source [2].

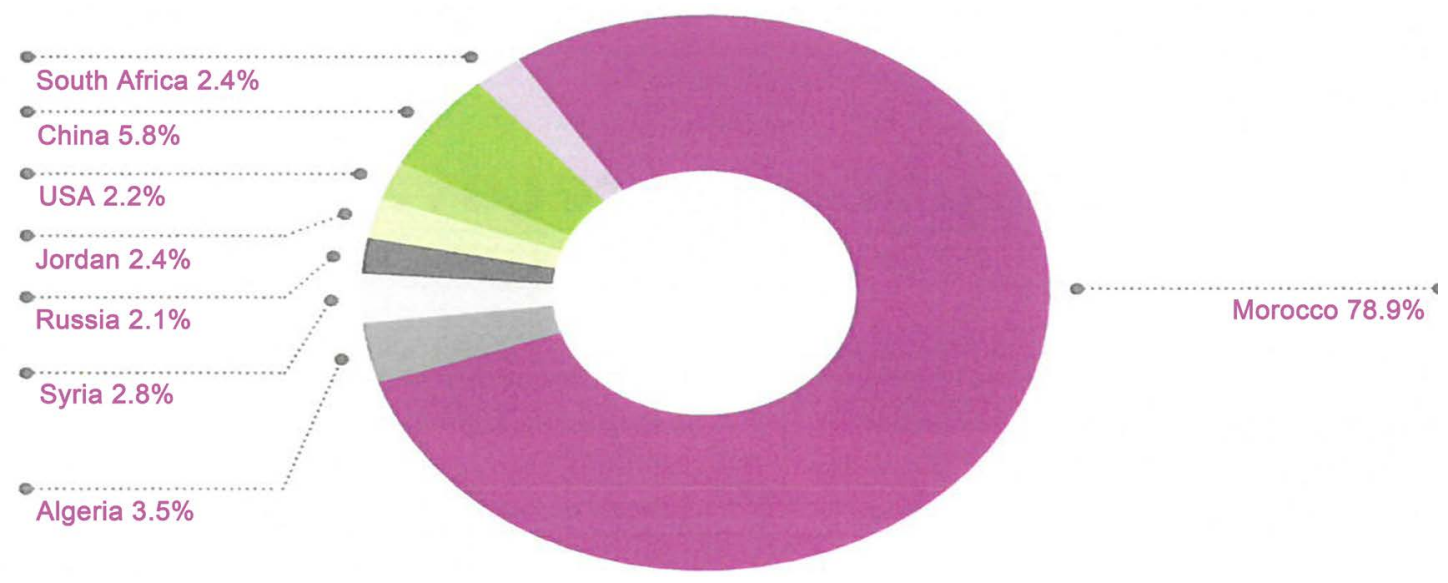

Figure 2. A summary of the world phosphorus available in mine-resources, source [2].

around the world are, limited, see Figure 2.

- A total ban of recycling treated municipal sludge to farming land, due to the risks linked to pharmaceutical remains in the sludge. This in turn may start a build-up of multi-resistant bacteria;

- A requirement of the mono-incineration of municipal sludge;

- An extraction of phosphate of sludge from the ashes from the mono incineration for plants serving more than 50,000 inhabitants.

\section{Objectives}

All these new circumstances include some "challenges" with respect to our current mode of wastewater treatment. In the following we will ask a few questions related to the very possible changes:

1) We already have technologies developed to withdraw phosphorus from the wastewater. These technologies are up to now related to the sludge capture.

2) We have also been able to combine different processes within the wastewater treatment chain to find efficient use of chemicals for P-removal, see [1]. 
3) However, in the view of the new requirements on P-removal and reuse, should we reconsider the models for the removal?

There are at least two interesting treatment models to consider. These are discussed in the following:

- The biological phosphorus removal, including the Phostrip model, see [3];

- The post-precipitation based on the addition of a suitable chemical agent, combined with a rapid filtration stage to minimize the discharge of phosphorus to the receiving water body.

- However, the demands for an ongoing improvement of the wastewater treatment will very likely involve even more stringent effluent consent levels. Already the issue of complex compounds in the wastewater such as pharmaceutical remains has resulted in new regulations in for instance Germany and Switzerland.

These perspectives are discussed in the following, however, the focus is given to the advanced filtration of the wastewater.

\section{Biological Phosphorus Removal}

Biological phosphorus removal has been a well-known option within municipal wastewater treatment for many decades. Some interesting and relevant findings will be high-lightened in this paper.

- With the re-birth of the SBR-technology both pilot-plant operations and full-scale operations have been contributing to the process knowledge. As an example, reference is given to an 18-month study at an arctic plant in Sweden, see [4]. The most striking results were the biological process capacity to capture phosphorus at very low waste water temperatures. Figure 3 illustrates the matter, showing that the ability was maintained down to around $4.5^{\circ} \mathrm{C}$.

- The development of the biological phosphorus removal found an interesting model by the so called Phostrip process, see [3]. As shown in Figure 4, the process includes a combined sludge selector/Phostrip reactor. The model will enable the operation to produce a phosphorus-rich side stream with possibly low contents of "unwanted" matters such as those that would remain assimilated in the bio-sludge.

The clear "added value" with this concept model is the potentially rather clean and phosphorus-rich stream from the separate stripper. The added potential benefit of this model is discussed in the following chapter.

A partial biological phosphorus reduction has also been investigated using the model for "attached growth" in a denitrification process, see below.

\section{Filtartion Techniques in Wastewater Treatment}

\subsection{Rapid Sand Filtration for Polishing Treatment}

The use of rapid sand filtration in municipal wastewater treatment has been in practice since the 1970's. Early in this decade the development of the so-called "Dyna Sand Filter" had reached such a technological level that it was presented 


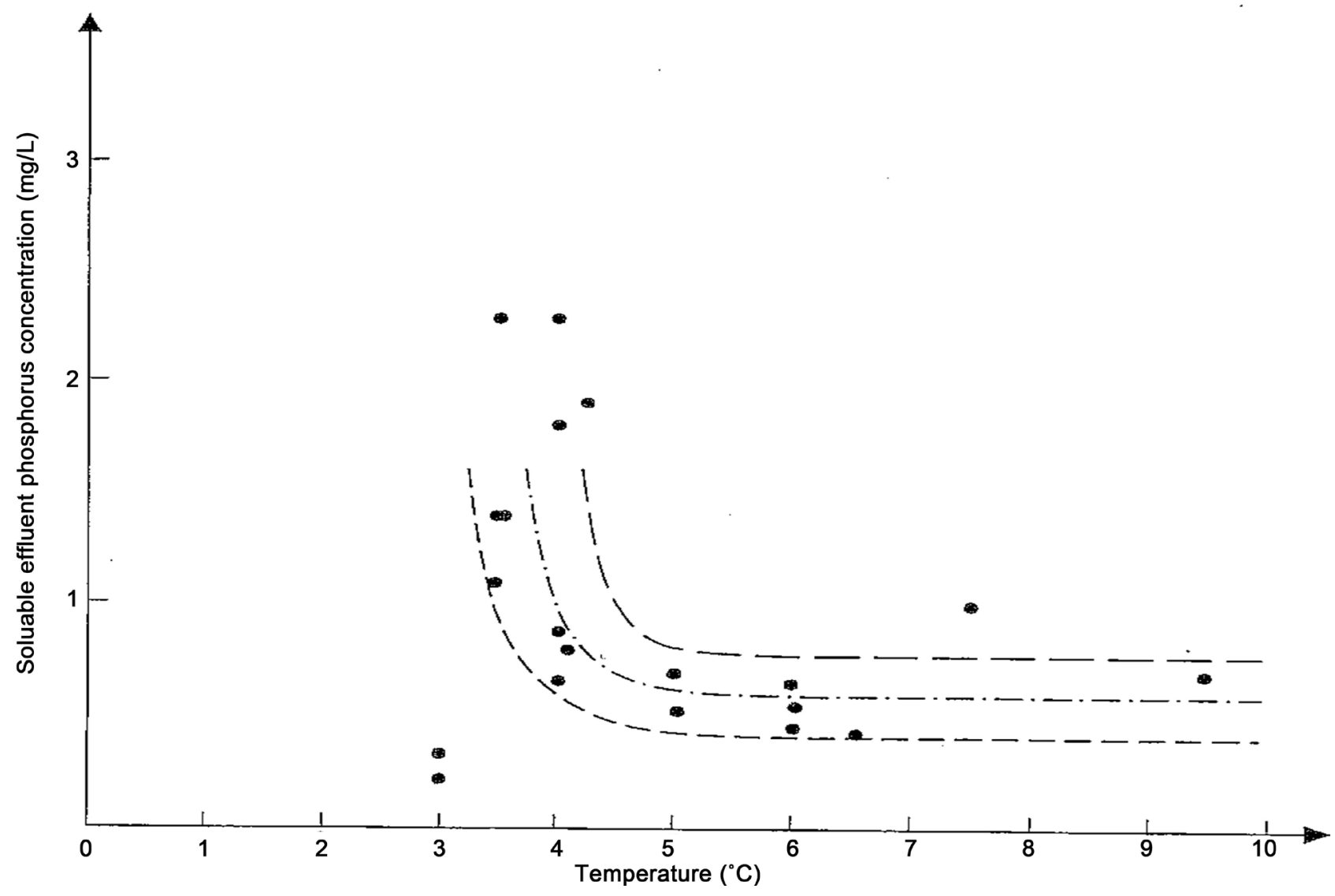

Figure 3. Outlet soluble phosphorus levels versus temperature (21 observations), see Marklund and Morling (1994).

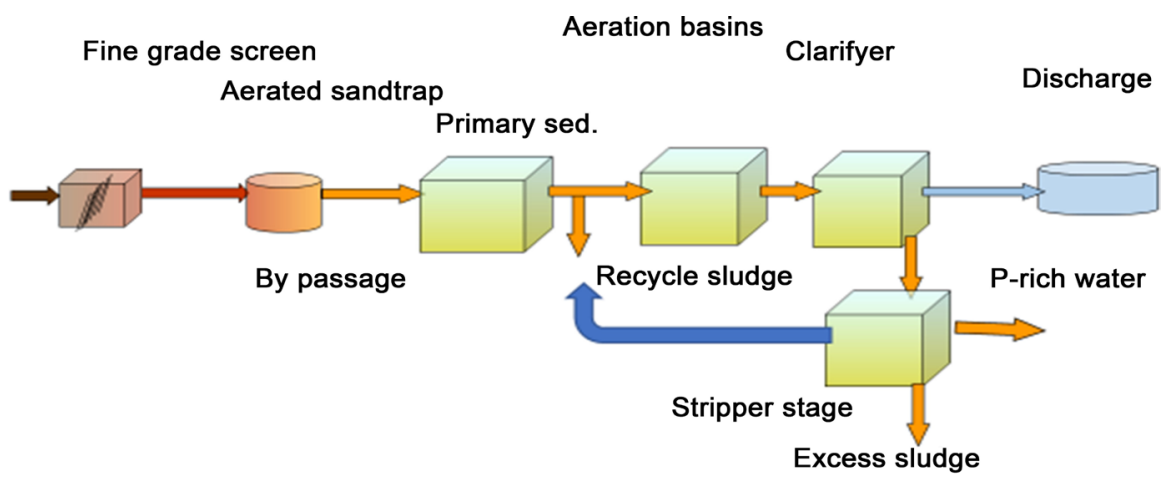

Biological Phosphorous removal by the Phostrip process

Figure 4. Principal flow sheet for the Phostrip process, presented at WEFTECH 2012.

for the Swedish market, see Figure 5. The driving forces for suitable application at WWTPs were a safe removal of SS and P removal. By convention the filters were installed as the final treatment step at the plants. The effluent demands in those years were rather "modest", with typical consent levels of $<0.5 \mathrm{ppm}$. These levels were normally met with ease and encouraged the operators to minimize the chemical dose. Typically, two competing chemical agents for P-removal were used in those years, Alum sulphate and Ferric chlorine.

More recent references are however relevant in our perspective. It is important 


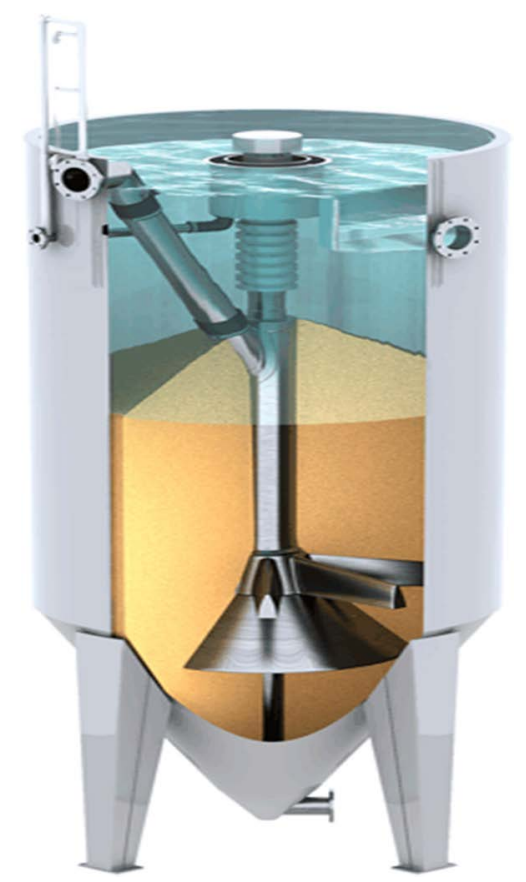

Figure 5. A standard unit for continuous sand filtration, as developed by the Johnson Group in Sweden (now in Nordic Water Products).

Table 1. Summary of discharge values from some Swedish municipal plants with respect to $\mathrm{P}$ (annual mean values).

\begin{tabular}{ccc}
\hline Plant name and size & Control year & Discharge level \\
\hline Klagshamn WWTP, Malmö 90,000 pe & 2014 & $0.20 \mathrm{mg} \mathrm{P/1}$ \\
Duvbacken WWTP, Gävle 107,000 pe & 2015 & $0.27 \mathrm{mg} \mathrm{P/1}$ \\
Torna Hällestad WWTP 800 pe & 2014 & $0.10 \mathrm{mg} \mathrm{P/1}$ \\
Nynäshamn WWTP 25,000 pe & 2012 & $0.06 \mathrm{mg} \mathrm{P/1}$ \\
Käppala WWTP 425,000 pe & 2014 & $0.20 \mathrm{mg} \mathrm{P/1}$ \\
Solviken WWTP, Mora 18,000 pe & 2015 & $0.14 \mathrm{mg} \mathrm{P/1}$ \\
Ellinge WWTP, Eslov 330,000 pe & 2014 & $0.19 \mathrm{mg} \mathrm{P/1}$ \\
\hline
\end{tabular}

to keep in mind that the knowledge with respect to P-removal has been important throughout the years. In reference [1] is found the "normal" discharge levels from several Swedish plants, see Table 1.

Comments on the presented plants in the table with respect to the results:

1) All $P$ discharge values are annual values, based on many samples.

2) All plants, except for Torna Hällestad and Mora, include requirements on nitrogen removal as well. Typical discharge levels for all these plants are $<10 \mathrm{mg}$ total $\mathrm{N} / \mathrm{l}$ as annual values.

3) All discharge levels with respect to $\mathrm{BOD}_{7}$ are found to be in the range 3 to10 $\mathrm{mg} / \mathrm{l}$.

4) The Duvbacken WWTP is operated mainly with an enhanced biological phosphorus removal, and a minor polishing addition of alum to safeguard the 
stipulated effluent requirement of $<0.3 \mathrm{mg} P / 1$.

5) The Ellinge plant treats a large amount of industrial wastewater, whereas the municipal contri-bution is $<30,000$ pe or $10 \%$.

6) The only plant operated with a final polishing filter stage is Solviken WWTP, however using another type of sand filter than the Dyna Sand model.

Now, some Swedish plants have been built with the Dyna Sand filter as the final treatment step. In the following recent performance results are presented. These are based on information from Nordic Water Products and from the official Annual Environmental reports that are public documents from all Swedish Water and Sewage organisations.

Figure 6 presented a 20-year record from the Sundet WWTP plant, serving the city of Växjö in the southern part of Sweden. Some key data for the plant is summarized as follows:

- The process chain contains a classical pre-treatment, including screens and sand/grit removal, primary sedimentation, followed by a classic activated sludge plant for biological removal of nitrogen, and a final stage for advanced phosphorus removal based on chemical addition and sand filters.

- Design organic pollution is $6650 \mathrm{~kg} \mathrm{BOD}_{7} / \mathrm{d}$, equal to around 95,000 person-equivalents.

- Real pollution loadings during 2017 show that the level was around 50,000 person-equivalents;

- The average wastewater flow during 2107 was slightly higher than $7000 \mathrm{~m}^{3} / \mathrm{d}$, or $140 \mathrm{l} / \mathrm{c} / \mathrm{d}$.

As may be seen the P-discharge level from the sand filters almost constantly have been at $0.1 \mathrm{ppm}$ or even lower throughout the years. The latest reported year, 2017 to the authorities is presented in Table 2, see also [5].

For year 2018 the following discharge levels from the plant are reported, see Table 3.

These results are as seen very stable and will be discussed further in the next chapter.
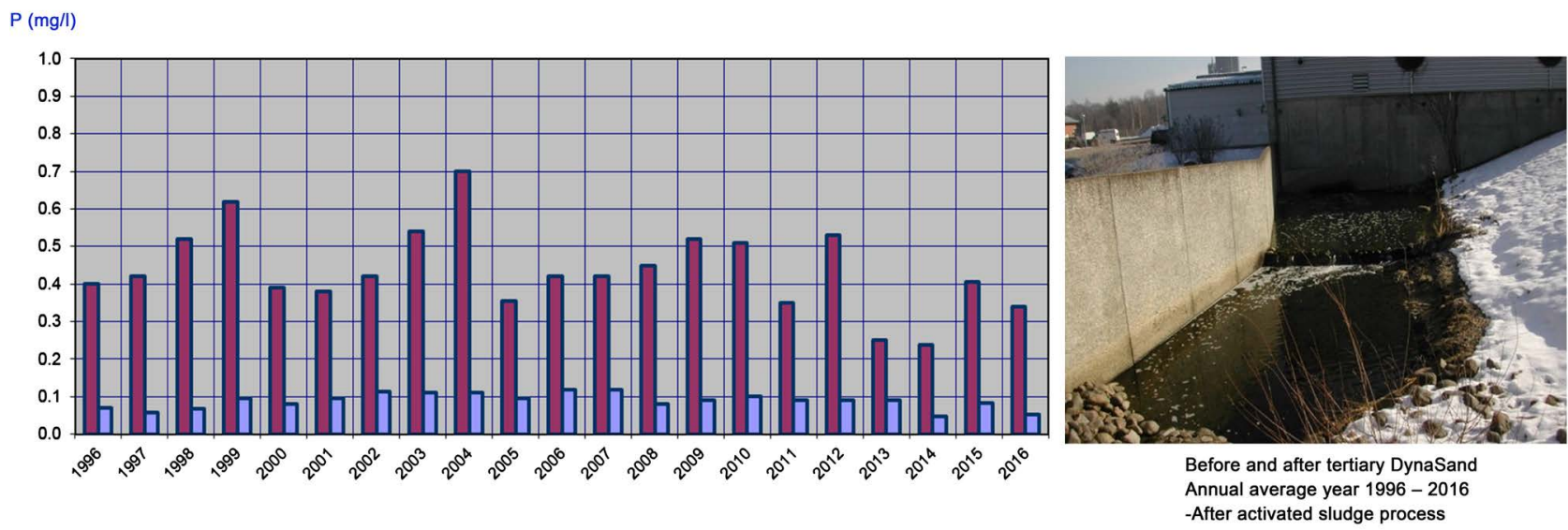

Figure 6. Report on inlet and outlet total P-levels at the Sundet WWTP, serving the city of Växjö (presentation elaborated by Nordic Water Products). 
Table 2. Summary of discharge values from Sundet, Växjö WWTP year 2017 with respect to the ruling effluent demand (based on totally 52 flow proportional samples).

\begin{tabular}{ccccc}
\hline Quarter & $\mathrm{BOD}_{7}, \mathrm{mg} / \mathrm{l}$ & Total $\mathrm{P}, \mathrm{mg} / \mathrm{l}$ & $\mathrm{NH}_{4}-\mathrm{N}, \mathrm{mg} / \mathrm{l}$ & Total N, mg/l \\
\hline Q1 & $<3$ & 0.062 & 5.3 & 19 \\
Q2 & $<3$ & 0.069 & 4.3 & 17 \\
Q3 & $<3.1$ & 0.070 & 3.1 & 14 \\
Q4 & $<3$ & 0.047 & 3.5 & 14 \\
\hline
\end{tabular}

Table 3. Summary of discharge values from Sundet, Växjö WWTP year 2018 with respect to the ruling effluent demand (based on totally 52 flow proportional samples).

\begin{tabular}{ccccc}
\hline Quarter & $\mathrm{BOD}_{7}, \mathrm{mg} / \mathrm{l}$ & Total $\mathrm{P}, \mathrm{mg} / \mathrm{l}$ & $\mathrm{NH}_{4}-\mathrm{N}, \mathrm{mg} / \mathrm{l}$ & Total N, mg/l \\
\hline Q1 & 1.5 & 0.1 & 5.8 & 19 \\
Q2 & 1.6 & 0.077 & 2.6 & 12 \\
Q3 & 1.5 & 0.078 & 2.2 & 10 \\
Q4 & 1.5 & 0.038 & 3.9 & 16 \\
\hline
\end{tabular}
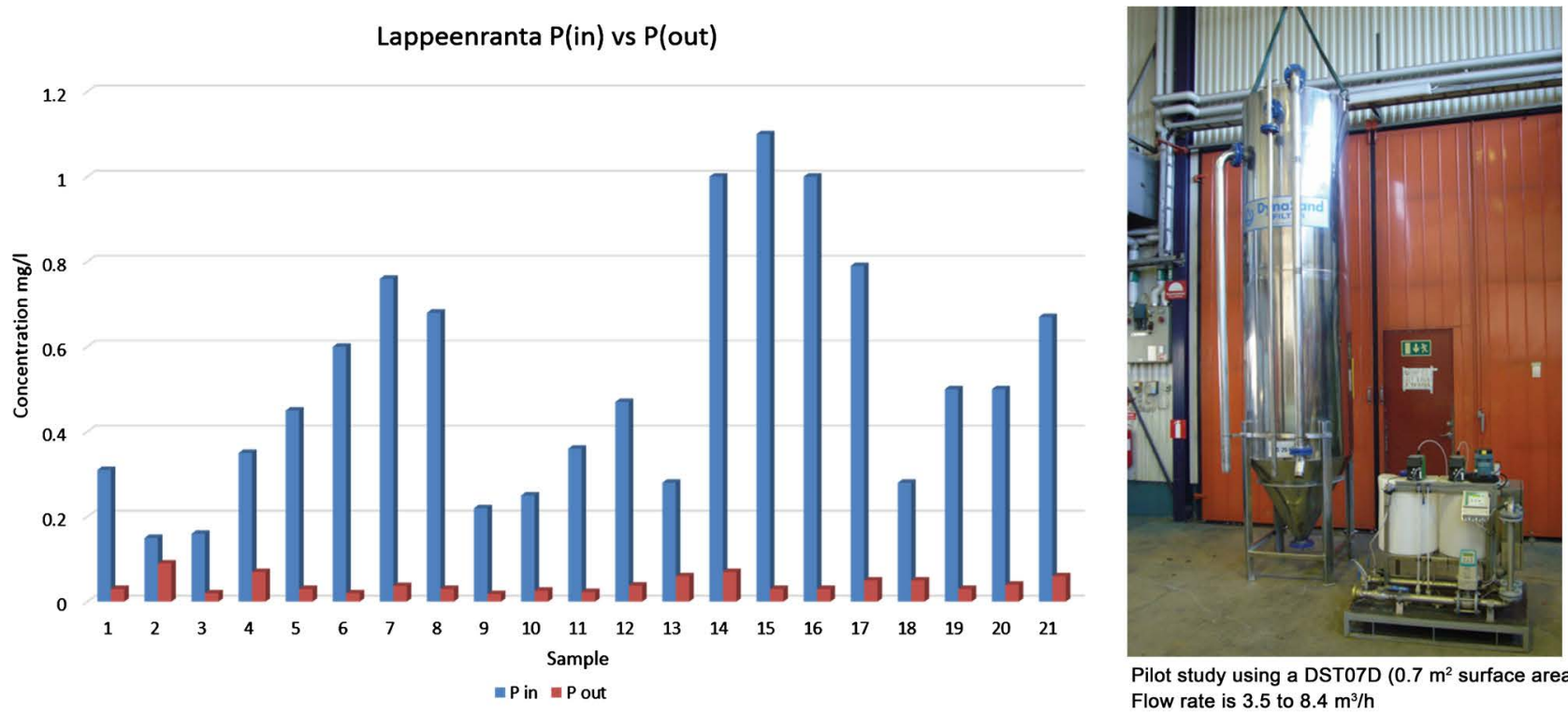

Pilot study using a DST07D $\left(0.7 \mathrm{~m}^{2}\right.$ surface area) Flow rate is 3.5 to $8.4 \mathrm{~m}^{3} / \mathrm{h}$

Hydraulic Loading Rate is 5 to $12 \mathrm{~m} / \mathrm{h}$ Dosing with aluminium chloride

Figure 7. Report on inlet and outlet total P-levels at the pilot plant operation for the Lappeenranta WWTP, Finland (presentation elaborated by Nordic Water Products).

Similar performance figures are presented from a pilot study that Nordic Water Products has conducted in the town of Lappenranta, Finland, see Figure 7.

The test results from Lappeenranta confirm the efficiency and process stability for the combined chemical precipitation along with a rapid sand filtration separation.

\subsection{Continuous Sand Filter Used as an Attached Growth Denitrification Reactor}

Pilot plant tests have been performed on the possibilities to test an attached 
growth denitrification by using the dyna sand filter. These tests included an operation aiming for a biological phosphorus removal. The outcomes of the tests are presented at an international seminar, see [6] and a summary of the results in Table 4.

\subsection{Disc Filter System for Polishing Treatment}

A development of the filtration technique is the models with drum filters and disc filters that have taken place during recent decades. For the polishing applications the disc filters with fine grade mesh of 20 to $60 \mu$ have gained the most interest. In Figure 8 is shown an illustration of a disc filter model that is marketed worldwide. The maker is the Swedish company Nordic Water Products. The model has been marked by the name "DynaDisc".

The disc filter model when used as a polishing stage has some limitations and clear requirements that should be noted.

- Firstly, the effluent requirements must be clearly stated; These would normally cover both suspended solids and phosphorus;

- Secondly, the design conditions with respect to flow variations, variations in especially suspended solids in inlet water should be defined;

- It is always valuable to define the prevailing wastewater temperature;

- The findings so far have clearly demonstrated that the addition of a polymer agent is indispensable, whereas the addition of a metal salt (alum or Ferric salt) is linked to the demand for phosphorus removal;

Table 4. Summary of test results from a test on phosphorus and nitrogen removal, as presented by Rathnaweera, S. S. et al. [6].

\begin{tabular}{|c|c|c|c|}
\hline P-removal & & & \\
\hline Inlet & $\begin{array}{l}\mathrm{Min} \\
\mathrm{mg} / \mathrm{l}\end{array}$ & $\begin{array}{c}\text { Average } \\
\mathrm{mg} / \mathrm{l}\end{array}$ & $\begin{array}{l}\mathrm{Max} \\
\mathrm{mg} / \mathrm{l}\end{array}$ \\
\hline Total P & 0.2 & 1.73 & 7.3 \\
\hline $\mathrm{PO}_{4}-\mathrm{P}$ & $<0.01$ & 0.64 & 4.1 \\
\hline SS & 8 & 41 & 169 \\
\hline \multirow[t]{2}{*}{ Discharge } & Min & Average & $\operatorname{Max}$ \\
\hline & $\mathrm{mg} / \mathrm{l}$ & $\mathrm{mg} / \mathrm{l}$ & $\mathrm{mg} / \mathrm{l}$ \\
\hline $\mathrm{TP}$ & 0.09 & 0.73 & 3.12 \\
\hline $\mathrm{PO}_{4}-\mathrm{P}$ & $<0.01$ & 0.4 & 2.34 \\
\hline SS & 3 & 16 & 57 \\
\hline \multirow[t]{2}{*}{ N-removal } & Min & Average & $\operatorname{Max}$ \\
\hline & $\mathrm{mg} / \mathrm{l}$ & $\mathrm{mg} / \mathrm{l}$ & $\mathrm{mg} / \mathrm{l}$ \\
\hline Total N & 8 & 15.1 & 27 \\
\hline $\mathrm{NO}_{3}-\mathrm{N}$ & 5.3 & 11.1 & 20.3 \\
\hline
\end{tabular}

Comments: These results give indications that the sand filter model used as a so called MBBR unit (Moving Bed BioReactor) may be used, however in the current perspective the results are more to show the versatile options for a sand filter system. 
- Whenever a pilot test is performed it is essential to clarify the operating conditions, such as to define any process or mechanical limitations for the specific application. This in turn makes it important to underline that a pilot plant test differs fundamentally from a demonstration plant that is more to confirm the success of a proposed application.

An interesting example of a pilot test with the Disc Filter was performed at the large regional WWTP south of Stockholm, called Himmerfjärden WWTP. The test was done in year 2012. The test conditions were the following: The used type of filter cloth was a $20 \mathrm{~m}$ PE. As seen further in Figure 9, the inlet quality varied substantially, due to the operation conditions in the main biological treatment.

Figure 9 demonstrates the test result over the period. It is essential to observe the following:

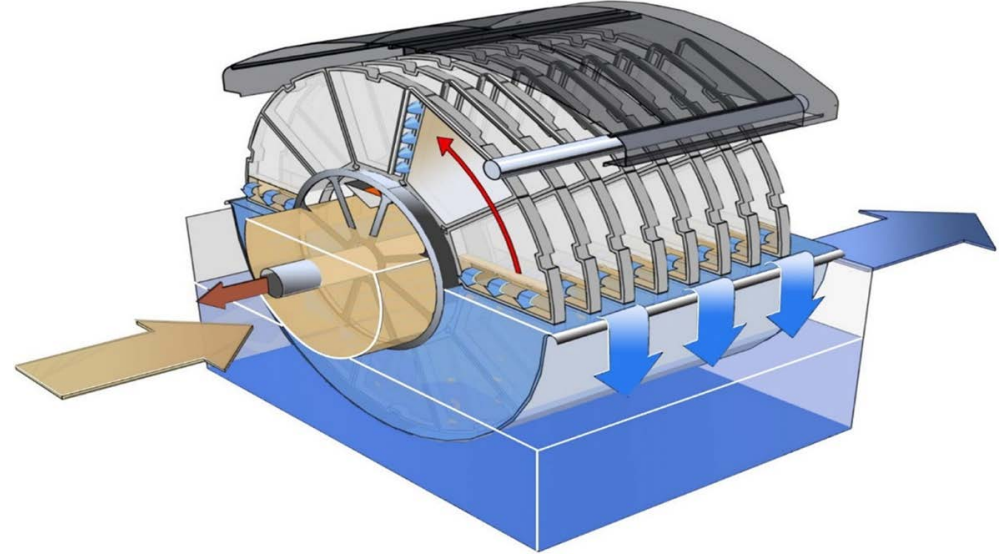

Figure 8. A typical disc filter unit found in the market for final separation of solids. (Source: Nordic Water Products).

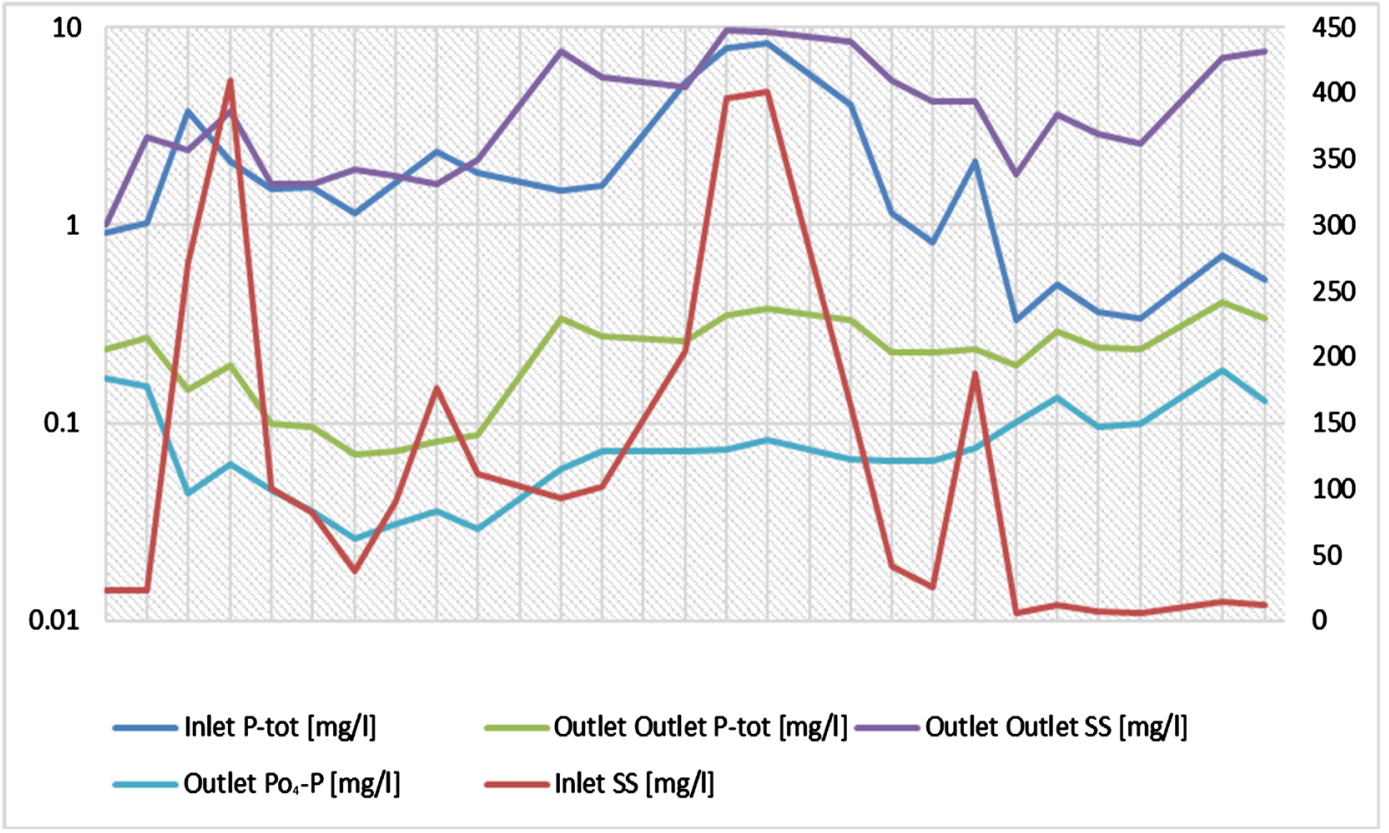

Figure 9. Tertiary treatment with DynaDisc combined with coagulation and flocculation. 
The substantial variation of the inlet SS has a limited effect on the discharge of phosphate phosphorus levels, these levels varies from around 0.05 to $0.12 \mathrm{mg} \mathrm{P} / \mathrm{l}$.

The evidently limiting factor is the inlet concentration of SS to the polishing stage. This in turn points out the necessity to understand the entire process, and not only the last polishing step, although this is providing a substantial removal.

\section{Discussion}

The presentation in this paper has focused on whether the $\mathrm{P}$ removal from municipal wastewater may be arranged in such a way that a high concentration of $\mathrm{P}$ is found in the removal streams. Two stages with very different process objectives may be interesting options to further develop. The first stage linked to the main biological treatment stage that may provide a side-stream with a high content of phosphorus. This stream in turn would need an additional treatment step, very likely by using precipitation + coagulation and filtration to capture the phosphorus. This stage could be developed by either a rapid sand filter system or by a disc filter model.

A key role for a successful development of far reaching separation of phosphorus will be the well-controlled biological phosphorus removal, including the Phostrip process. The final separation by means of a filter stage is today a very well-established technology that may provide not only very low effluent levels of the phosphorus, stable effluent levels may be established at $<0.1 \mathrm{ppm}$. A total capture of the phosphorus load may be $>97 \%$

\section{Summary and Conclusions}

The filtration has demonstrated to be an efficient way to reach very low discharge levels of phosphorus, thus representing an attractive option whenever strict effluent standard removal is stipulated. This in turn means that a rather "clean" backwashing stream with phosphorus is created. A further interesting possibility is thus to recover the phosphate from the water. The matter may even be improved if a biological phosphorus removal is arranged with a following "Phostrip" process that allows a final removal of the phosphorus from the sludge-water stream, by using the same coagulation/filtration model as used for the polishing step.

What are the crucial questions to consider for this model? Two main issues must be raised and further analyzed:

- The feasibility with respect to operating costs;

- To clearly identify the impurities in the water and concentrated phosphorus-rich streams, such as complex organic compounds, pharmaceutical remains and heavy metals.

\section{Acknowledgements}

Mr Steve Karlsson, process manager at the Water and Wastewater Entity at Växjö city has provided operation results from the main treatment plant, Sun- 
det.

Professor em. Jan Rennerfelt (KTH) has kindly scrutinized the text from historical and technical viewpoints and approved the findings.

Mr Göran Arnkil at Nordic Water Products for technical comments regarding filtration systems.

Mr Guy Taylor who has scrutinized the linguistics in the text.

\section{Conflicts of Interest}

The authors declare no conflicts of interest regarding the publication of this paper.

\section{References}

[1] Morling, S. (2019) Swedish Experience and Excellence in Wastewater Treatment Demonstrated Especially in Phosphorus Removal. Journal of Water Resource and Protection, 11, 333-347. https://doi.org/10.4236/jwarp.2019.113019 http://www.scirp.org/journal/jwarp

[2] Weichmann, B., Dienemann, C., Kabbe, Ch., Brandt, S., Vogel, I. and Roskosch, A. (2016) Sewage Sludge Management in Germany. Umweltbuntesamt c/o GVP, Bonn, German.

[3] Kaschka, E. and Weyrer, S. (1999) Phostrip Handbook, Biological Elimination of Phosphorus from Domestic Sewage by Applying the Enhanced Phostrip Process. Fourth Edition.

[4] Marklund, S. and Morling, S. (1994) Biological Phophorus Removal at Temperatures from 3 to $10^{\circ} \mathrm{C}-\mathrm{A}$ Full Scale Study of a Sequencing Batch Reactor Unit. Canadian Journal of Civil Engineering, 21, 81-88

[5] Community of Växjö (2017) Annual Environmental Report for the WWTP at Sundet. Official Report in Swedish regarding the Main Treatment Plant for the Main WWTP Serving the Community.

[6] Rathnaweera, S.S., Rusten, B., Gjevre, J. and Tranum, I. (2018) Evaluation of Moving Bed Sand Filter to Achieve Very Low Total Phosphorus Limit with Simultaneous Denitrification and Suspended Solids Removal from Municipal Wastewater. Ullensaker Municipality, Jessheim, Norway. 